\title{
Maastricht University graduate surveys 2014
}

Citation for published version (APA):

Belfi, B. E., \& Meng, C. M. (2014). Maastricht University graduate surveys 2014. ROA. ROA Fact Sheets No. 005 https://doi.org/10.26481/umarof.2014005

Document status and date:

Published: 01/01/2014

DOI:

10.26481/umarof.2014005

Document Version:

Publisher's PDF, also known as Version of record

\section{Please check the document version of this publication:}

- A submitted manuscript is the version of the article upon submission and before peer-review. There can be important differences between the submitted version and the official published version of record.

People interested in the research are advised to contact the author for the final version of the publication, or visit the DOI to the publisher's website.

- The final author version and the galley proof are versions of the publication after peer review.

- The final published version features the final layout of the paper including the volume, issue and page numbers.

Link to publication

\footnotetext{
General rights rights.

- You may freely distribute the URL identifying the publication in the public portal. please follow below link for the End User Agreement:

www.umlib.nl/taverne-license

Take down policy

If you believe that this document breaches copyright please contact us at:

repository@maastrichtuniversity.nl

providing details and we will investigate your claim.
}

Copyright and moral rights for the publications made accessible in the public portal are retained by the authors and/or other copyright owners and it is a condition of accessing publications that users recognise and abide by the legal requirements associated with these

- Users may download and print one copy of any publication from the public portal for the purpose of private study or research.

- You may not further distribute the material or use it for any profit-making activity or commercial gain

If the publication is distributed under the terms of Article $25 \mathrm{fa}$ of the Dutch Copyright Act, indicated by the "Taverne" license above, 
Tuastricht University in Learning!

Research Centre for Education and the Labour Market | ROA

\title{
Maastricht University graduate surveys 2014
}

\section{ROA Fact Sheet}

\author{
ROA-F-2014/5
}

Researchcentrum voor Onderwijs en Arbeidsmarkt | ROA Research Centre For Education and the Labour Market / ROA 


\section{Maastricht University graduate surveys 2014}

To which degree does Maastricht University succeed in preparing its students for the labour market? What are the short and medium term career paths of Maastricht University alumni, and how do they look back on their study in Maastricht? In this factsheet, the most important results are presented of a 2013/20I4 survey amongst three cohorts of Maastricht University alumni. The first cohort graduated in the academic year 2OII-2OI2 (I,5 year prior to the survey), the second cohort graduated in 2007-2008 ( 6 years prior to the survey) and the third cohort in the academic year 2002-2003 (II years prior to the survey). ${ }^{\mathrm{I}, 2}$

\section{Position in the labour market}

Six to eleven years after graduation, around $95 \%$ of the Maastricht university alumni have paid employment. Of those not currently working, a small percentage is searching for work, which means that overall approximately $2 \%$ of graduates in both cohorts reported to be out of the labour force. Important reasons for inactivity include participating in further education or to be taking care of children or relatives. Table I gives a more detailed overview of graduates' employment rates - that is, the proportion who is not currently working but who is searching for work - by cohort and faculty. Overall, $14 \%$ of the $201 \mathrm{I}-2012$ cohort is currently without a job, while only $3 \%$ of the $2007-2008$ cohort and $2 \%$ of the 2002-2003 cohort are unemployed. ${ }^{3}$ The considerably higher unemployment rate of the 20II2012 cohort seems to be a clear reflection of the current economic crisis.

In the 2OII-2OI2 cohort, unemployment rates are above average for Arts and Social Sciences and Psychology and Neuroscience graduates, below average for Business and Economics and Health, Medicine and Life Sciences graduates, and average for Law graduates. In the two elder cohorts, differences in unemployment rates are less pronounced. All things considered, we can conclude that labour market participation is very high for the 2007-2008 and 2002-2003 cohorts of Maastricht university graduates, but is considerably lower for the $20 \mathrm{II}-20 \mathrm{I} 2$ cohort.

I. For the 20II-20I2 cohort, 3030 respondents were approached, of whom $25 \%$ responded. For the $2007-2008$ cohort, of the 1370 alumni approached, $38 \%$ responded. Finally, for the 2002-2003 cohort, of the I346 alumni that were approached, $39 \%$ responded.

2. The reader should keep in mind that the mix of studies offered by Maastricht University the respondents graduated from, might vary between the three cohorts.

3. The unemployment rate might also vary within faculties. For example, in case of the Faculty of Health, Medicine and Life Sciences, the unemployment of Medical alumni, is between $\mathrm{I} \%$ and $2 \%$ for the two older cohorts, whereas for Health and Life Sciences alumni the unemployment rate is $4 \%$.
Table 1

Unemployment ${ }^{1}$

\begin{tabular}{|l|c|c|c|}
\hline & \multicolumn{3}{|c|}{ \% unemployed } \\
\hline Business and Economics & $2011-2012$ & $2007-2008$ & $2002-2003$ \\
\hline Health, Medicine and Life Sciences & 6 & 0 & 1 \\
\hline Arts and Social Sciences & 11 & 3 & 3 \\
\hline Psychology and Neuroscience & 33 & 5 & $x$ \\
\hline Law & 26 & 4 & 5 \\
\hline Maastricht University & 14 & 4 & 0 \\
\hline
\end{tabular}

$1=$ too little information about the Faculty of Humanities and Sciences $x=$ too few cases

\section{Trends in unemployment}

To which extent has the economic crisis affected labour market opportunities of Maastricht University graduates since 2008? In quest of an answer to this question, we have analysed the average unemployment rate of Maastricht university graduates, as reported by the surveys that were held between 2005 and 2013. For all nine years that these surveys were conducted, unemployment information of the three cohorts is available. For the two cohorts that are 6 or II years on the labour market, no visible trend in unemployment rates can be detected. Especially when comparing within cohorts over time, unemployment rates fluctuate trendless. Thus, the current economic crisis does not seem to have an influence on the unemployment rate of Maastricht University alumni 6 to II years into their labour market. Nevertheless, a notable increase in unemployment rates can be observed when analysing the data of alumni who graduated one year prior to the survey (see Figure I). In Appendix A, yearly employment rates are reported per faculty.

\section{Figure 1}

Trends in unemployment of the T+1 survey ${ }^{1}$

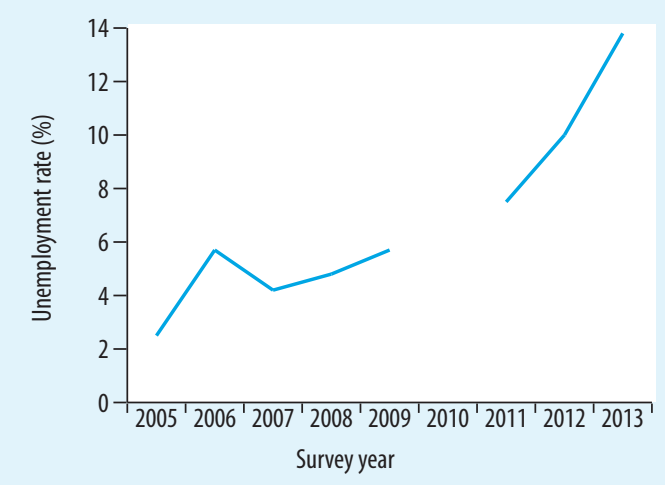

$1=$ the $T+1$ survey was not administered in 2010

\section{Job characteristics}

It is important that graduates have a good match between their education and the requirements of their job, since this determines the extent to which they can use their knowledge and skills. The quality of the education-job 
match is therefore also positively related to job satisfaction, career opportunities, and wages. An important indicator of the quality of the fit between education and the job, is the vertical match (i.e., whether graduates are working in a job for which a university degree is required). Table 2 a shows the results of the vertical match between graduates' current job and their level of education, for all three cohorts.

\section{Table 2a}

Vertical match

\begin{tabular}{|l|c|c|c|} 
& \multicolumn{4}{|c}{ \% working at university level or higher } \\
& $2011-2012$ & $2007-2008$ & $2002-2003$ \\
\hline Business and Economics & 79 & 94 & 87 \\
\hline Health, Medicine and Life Sciences & 84 & 93 & 85 \\
\hline Arts and Social Sciences & 82 & 88 & X \\
\hline Psychology and Neuroscience & 72 & 91 & 87 \\
\hline Law & 78 & 88 & 81 \\
\hline Maastricht University & 80 & 91 & 84
\end{tabular}

$1=$ too little information about the Faculty of Humanities and Sciences $\mathrm{x}=$ too few cases

The results of the vertical match are substantially different for the three cohorts. For all faculties, considerably more alumni are working at university level in the 2007-2008 cohort as compared to the 20II-20I2 and 2002-2003 cohorts. In all three cohorts, graduates from the Faculty of Health, Medicine and Life Sciences show above average figures. ${ }^{4}$ In the 2OII-2OI2 cohort, also graduates from the Faculty of Arts and Social Sciences show above average figures and in the 2007-2008 cohort, also graduates from the School of Business and Economics. In the 2002-2003 cohort, next to Health, Medicine and Life Sciences-degree holders, also graduates with a degree in Business and Economics and Psychology and Neuroscience are above average employed in university-level jobs. Notably, while the Faculty of Psychology and Neuroscience has above average figures for the 2002-2003 cohort and average figures for the 2007-2008 cohort, in the $201 \mathrm{I}-2 \mathrm{OI} 2$ cohort, the figures are far below the average. In addition, it should be noted that these outcomes are highly correlated with degree specificity as well as labour market condition in the particular field. In all disciplines and for all three cohorts, the percentage of graduates with an above average vertical match increased remarkably between the first and the current job.

Another important indicator of the quality of the fit between education and the job, is the horizontal match (i.e., whether graduates are working in a job for which their own or a related field of study is required). Table $2 b$ presents the proportion of Maastricht University graduates who show

4. For the Faculty of Health, Medicine and life Sciences a strong difference is again visible between Medicine (in all three cohorts I00\% of the graduates are perfectly vertically matched) and Health and Life Sciences. Graduates of the latter studies perfectly vertically matched in $69 \%$ (20II-20I2), 87\% (2007-2008), and 80\% (2002-2003) of the cases. a good horizontal education-job-match. The results clearly show different results for the three cohorts, with the results being most positive for the 2007-2008 cohort. 6 years after graduation, $82 \%$ of the Maastricht University graduates are working in a job that matches the field of study, while I,5 and II years after graduation, respectively only $75 \%$ and $74 \%$ of the Maastricht university graduates are working in the own or a related field of study. For the latter two cohorts, the underlying reasons for a horizontal mismatch might differ. Shortly after graduation, a horizontal mismatch is often related to labour market conditions not allowing graduates to find a job that matches the field of study, as well as voluntary choices preferring a job in a different field. II years after graduation, upward job mobility often comes with more 'generic' positions not directly related to the initial field of study.

Table $2 b$

Horizontal match

\begin{tabular}{l|c|c|c|} 
& \multicolumn{3}{|c|}{ \% working in own or related field of study } \\
\hline Business and Economics & $2011-2012$ & $2007-2008$ & $2002-2003$ \\
\hline Health, Medicine and Life Sciences & 73 & 81 & 71 \\
\hline Arts and Social Sciences & 82 & 89 & 78 \\
\hline Psychology and Neuroscience & 68 & 64 & $\mathrm{X}$ \\
\hline Law & 61 & 84 & 80 \\
\hline $\begin{array}{l}\text { Maastricht University } \\
\text { 1= too little information about the Faculty of Humanities and Sciences } \\
\text { x = too few cases }\end{array}$
\end{tabular}

Next to differences between the three cohorts, also differences between the various faculties can be observed. Graduates from the Faculty of Health, Medicine and Life Sciences and the Faculty of Law have above average figures for all three cohorts. It should be noted, however, that within the Faculty of Health, Medicine and Life Sciences, a strong distinction can be seen between the study of Medicine and the studies of Health and Life Sciences. Because of the very specific nature of their study, Medicine graduates, show a considerably better horizontal match in all three cohorts (2OII-20I2: 93\%, 2007-2008: 100\%, 2002-2003: 100\%) than the graduates of Health and Life Science studies (2OII-2OI2: 74\%, 2007-2008: 78\%, 2002-2003: 70\%). Graduates from the Faculty of Arts and Social Sciences and the School of Business and Economics have below average figures for all three cohorts. Remarkably, while the Faculty of Psychology and Neuroscience has above average figures for the 20072008 and 2002-2003 cohorts, in the 20II-20I2 cohort, the figures are far below the average.

\section{Income and working hours}

Table 3 shows that, as can be expected, as working experience increases, the median gross income of Maastricht University 
alumni also increases. More specifically, I,5 year after graduation, Maastricht University alumni have a median income of $€ 2.500$ per month, 6 years after graduation they have a median income of $€ 3.585$ per month ( $43 \%$ more than the starting salary), and II years after graduation they have a median income of $€ 4.300$ per month ( $72 \%$ more than the starting salary). These numbers closely match the results of previous surveys, although the median incomes have slightly dropped. Although the income patterns across disciplines slightly differ between the different survey years, Business and Economics graduates consistently show the highest monthly earnings and Arts and Social Sciences graduates the lowest. ${ }^{6}$ It should be noted however, that graduates of the top income discipline (Business and Economics) also report the highest working hours, compared to graduates of the other disciplines. This is particularly the case for the 2OII-2OI2 and 2002-2003 cohort.

\section{Table 3}

Income and working hours ${ }^{1}$

\begin{tabular}{|c|c|c|c|c|c|c|}
\hline & \multicolumn{3}{|c|}{$\begin{array}{l}\text { gross income per month } \\
\text { (median) }\end{array}$} & \multicolumn{3}{|c|}{$\begin{array}{l}\text { regular working hours } \\
\text { per week }\end{array}$} \\
\hline & $\begin{array}{l}2011- \\
2012\end{array}$ & $\begin{array}{l}2007- \\
2008\end{array}$ & $\begin{array}{l}2002- \\
2003\end{array}$ & $\begin{array}{l}2011- \\
2012\end{array}$ & $\begin{array}{l}2007- \\
2008\end{array}$ & $\begin{array}{l}2002- \\
2003\end{array}$ \\
\hline Business and Economics & 3.048 & 5.250 & 5.667 & 40 & 40 & 40 \\
\hline Health, Medicine and Life Sciences & 2.625 & 3.500 & 4.000 & 37 & 38 & 33 \\
\hline Arts and Social Sciences & 1.608 & 3.000 & $x$ & 33 & 40 & $\mathrm{x}$ \\
\hline Psychology and Neuroscience & 2.019 & 3.050 & 3.500 & 32 & 38 & 32 \\
\hline Law & 2.820 & 3.600 & 4.200 & 38 & 40 & 36 \\
\hline Maastricht University & 2.500 & 3.585 & 4.300 & 37 & 40 & 36 \\
\hline
\end{tabular}

$1=$ too little information about the Faculty of Humanities and Sciences $\mathrm{x}=$ too few cases

\section{Job satisfaction}

The job satisfaction of Maastricht University graduates is generally high. Of the $20 \mathrm{II}-20 \mathrm{I} 2$ cohort, $73 \%$ of all employed alumni are satisfied with their jobs. For the 20072008 cohort the figure is $79 \%$ and for the $2002-2003$ cohort $8 \mathrm{r} \%$. The majority of the Maastricht University alumni (66\% of the $201 \mathrm{II}-20 \mathrm{I} 2$ and $2007-2008$ cohorts and $62 \%$ of the 2002-2003 cohort) also find that their current job offers good career opportunities (see Table 4 ).

5. In the estimation of the median gross income of the Maastricht University alumni, we did not control for any differences between graduates of the different faculties with respect to background characteristics such as country of residence, working hours, purchasing power parity, etc.

6. The relatively low median income of Health, Medicine and Life Sciences graduates, is strongly influenced by the relatively low median income of the Health and Life Sciences studies. Medical graduates (a) have a higher starting salary and (b) are the best paid alumni II years after graduation with a median income of $€ 6.900$. Due to the structure of their career paths, Medical alumni are also the group which displays the biggest income growth between six and eleven years after graduation.
Table 4

Job satisfaction, career opportunities

\begin{tabular}{|c|c|c|c|c|c|c|}
\hline & \multicolumn{3}{|c|}{$\%$ satisfied with job } & \multicolumn{3}{|c|}{$\begin{array}{l}\% \text { that thinks jobs } \\
\text { offers good career } \\
\text { opportunities }\end{array}$} \\
\hline & $\begin{array}{l}2011- \\
2012\end{array}$ & $\begin{array}{l}2007- \\
2008\end{array}$ & $\begin{array}{l}2002- \\
2003\end{array}$ & $\begin{array}{l}2011- \\
2012\end{array}$ & $\begin{array}{l}2007- \\
2008\end{array}$ & $\begin{array}{l}2002- \\
2003\end{array}$ \\
\hline Business and Economics & 74 & 81 & 82 & 68 & 79 & 75 \\
\hline Health, Medicine and Life Sciences & 78 & 81 & 84 & 75 & 65 & 59 \\
\hline Arts and Social Sciences & 72 & 76 & $x$ & 48 & 50 & $x$ \\
\hline Psychology and Neuroscience & 57 & 79 & 87 & 46 & 64 & 51 \\
\hline Law & 71 & 74 & 77 & 70 & 62 & 59 \\
\hline Maastricht University & 73 & 79 & 81 & 66 & 66 & 62 \\
\hline
\end{tabular}

$1=$ too little information about the Faculty of Humanities and Sciences $\mathrm{x}=$ too few cases

\section{International orientation of Maastricht University and its} graduates

The international orientation of Maastricht University and the fact that English is the main language of instruction in many study programs, appears to be attracting an increasing number of international students for all faculties. It is interesting to see whether this international orientation is extended beyond the time of the study in Mastricht, in the form of high percentages of graduates working abroad. Table 5 shows the percentage of Maastricht University alumni of the various cohorts who are currently working inside and outside the Netherlands, split by faculty. For Maastricht University as a whole, $38 \%$ of the alumni of 201 I2012 cohort are working abroad, $30 \%$ of the alumni of the $2007-2008$ are working abroad, and $20 \%$ of the alumni of the 2002-2003 are working outside the Netherlands. These numbers include foreign students who returned to their home country after graduation.

Considerable variation exists between the faculties. Graduates of the Arts and Social Sciences are particularly internationally active, closely followed by those of the School of Business and Economics and the Faculty of Psychology and Neuroscience. In the two youngest cohorts, more than $50 \%$ of the Arts and Social Sciences alumni were working in countries other than the Netherlands. This indicates that for alumni of the Faculty of Arts and Social Sciences, international labour markets are now more important than the Dutch labour market.

Asked to what extent Maastricht University prepared its students for the international labour market, 50\% of the $2007-2008$ cohort and $44 \%$ of the $2002-2003$ cohort responded that they felt prepared to a high or very high extent. There are large differences between faculties, which broadly reflect the differences in the proportions working abroad. Graduates of the School of Business and Economics and the Faculty of Arts and Social Sciences feel the most prepared for the international labour market. 
Table 5

Percentage currently working abroad ${ }^{1}$

\begin{tabular}{|c|c|c|c|c|c|c|}
\hline & \multicolumn{2}{|c|}{ 2011-2012 } & \multicolumn{2}{|c|}{$2007-2008$} & \multicolumn{2}{|c|}{$2002-2003$} \\
\hline & $\begin{array}{c}\text { well } \\
\text { prepared }\end{array}$ & $\begin{array}{c}\text { working } \\
\text { abroad }\end{array}$ & $\begin{array}{c}\text { well } \\
\text { prepared }\end{array}$ & $\begin{array}{l}\text { working } \\
\text { abroad }\end{array}$ & $\begin{array}{c}\text { well } \\
\text { prepared }\end{array}$ & $\begin{array}{r}\text { working } \\
\text { abroad }\end{array}$ \\
\hline Business and Economics & - & 57 & 85 & 50 & 74 & 40 \\
\hline Health, Medicine and Life Sciences & - & 17 & 31 & 13 & 32 & 8 \\
\hline Arts and Social Sciences & - & 67 & 57 & 57 & $\mathrm{x}$ & $\mathrm{x}$ \\
\hline Psychology and Neuroscience & - & 31 & 44 & 29 & 36 & 15 \\
\hline Law & - & 30 & 36 & 14 & 25 & 9 \\
\hline Maastricht University & - & 38 & 50 & 30 & 44 & 20 \\
\hline
\end{tabular}

$1=$ too little information about the Faculty of Humanities and Sciences

- = not administered in the 2011-2012 questionnaire

$\mathrm{x}=$ too few cases

\section{Satisfaction with study at Maastricht University}

Finally, alumni were asked how they looked back on their study at Maastricht University and to assess what choices they would make in retrospect. Would they choose for the same study at the same university again? In the 20II-20I2 cohort, $74 \%$ of the alumni would again choose the exact same study at Maastricht University. For the cohorts that graduated in 2007-2008 and 2002-2003, these figures were $73 \%$ and $75 \%$, respectively. Table 6 presents the survey results for the three cohorts per faculty. ${ }^{7}$

\section{Table 6}

Percentage of alumni who would again choose to study at Maastricht University

\begin{tabular}{|l|c|c|c|}
\hline & $2011-2012$ & $2007-2008$ & $2002-2003$ \\
\hline Business and Economics & 72 & 73 & 73 \\
\hline Health, Medicine and Life Sciences & 79 & 73 & 76 \\
\hline Arts and Social Sciences & 64 & 69 & $x$ \\
\hline Psychology and Neuroscience & 66 & 72 & 67 \\
\hline Law & 85 & 77 & 73 \\
\hline Maastricht University & 74 & 73 & 75 \\
\hline
\end{tabular}

$1=$ too little information about the Faculty of Humanities and Sciences $\mathrm{x}=$ too few cases

In line with these findings, $78 \%$ of the respondents report that their study at Maastricht University is still (very) useful for their current job. These results are consistent across faculties and cohorts. Even six and II years after graduation, Maastricht University graduates still feel strongly connected to their alma mater. As part of the survey, alumni were also asked whether Maastricht University could contact them to ask them to give a lecture or a presentation, to act as a contact person in their company should internships become available there, or to act as a 'mentor' for current students.

7. Within the Faculty of Health, Medicine and Life Sciences, graduates of the Medical studies are significantly more satisfied with their study choice in retrospect. For example, in the $2007-2008$ cohort, $63 \%$ of the graduates of Health and Life Sciences would again choose the same study at Maastricht University compared to $82 \%$ of the Medical graduates.
5 out of Io respondents indicated that they would like to be involved in at least one of these Maastricht University networks. 
Appendix A

Table 7

Trends in unemployment ${ }^{1}$

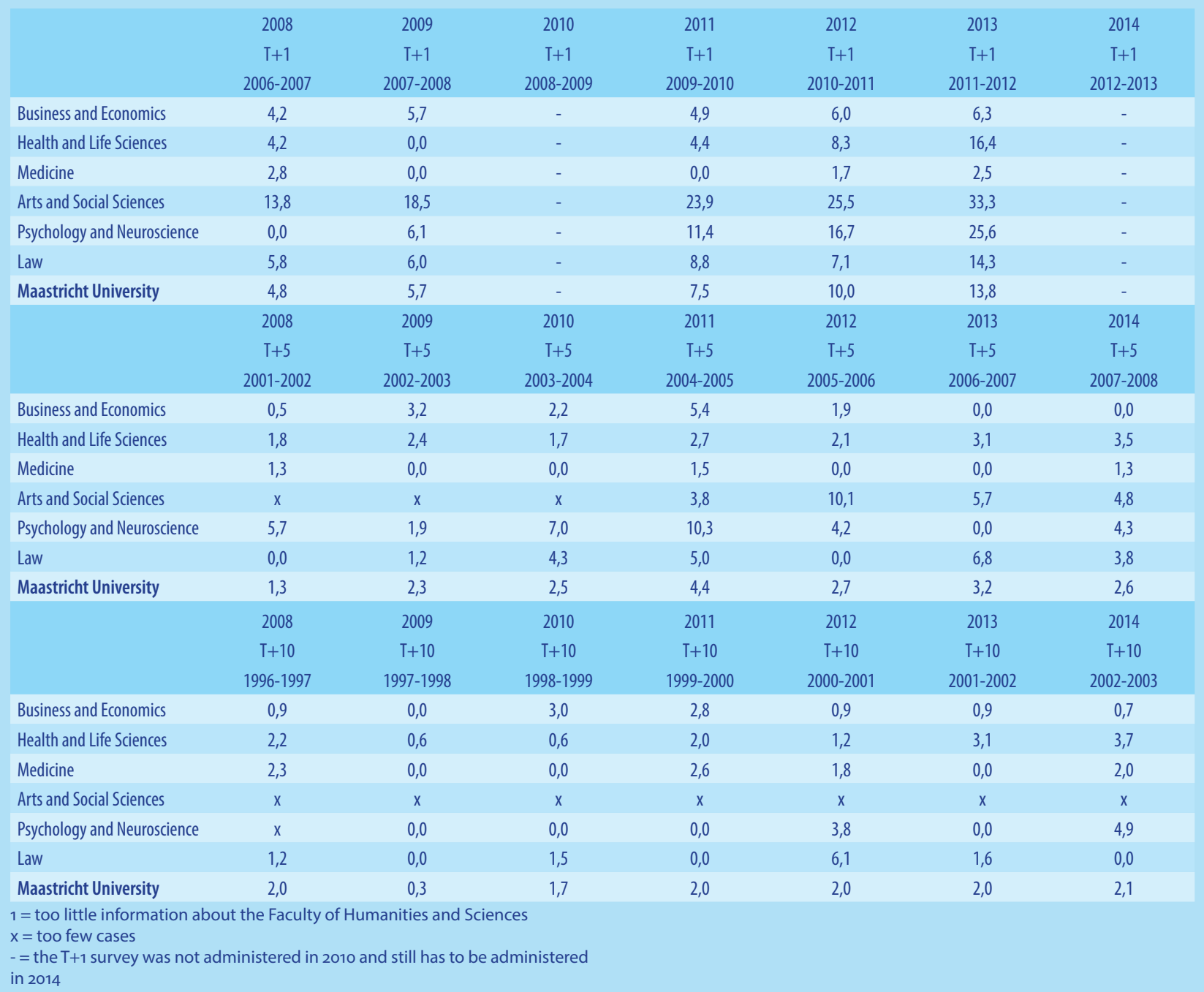




\section{Colofon}

Copyright (C) 20I4, Research Centre for Education and the Labour Market, Maastricht. No part of this publication may be reproduced in any way without prior permission of the Director of ROA.

Research Centre for Education and the Labour Market P.O. Box 616

6200 MD Maastricht

The Netherlands

secretary-roa-sbe@maastrichtuniversity.nl

www.roa.nl

Maastricht University

School of Business and Economics

\section{Layout}

ROA secretary, Maastricht

October 2014 
Researchcentrum voor Onderwijs en Arbeidsmarkt

Postbus 616

6200 MD Maastricht

$\mathrm{T}+31433883647$

F +31 433884914

secretary-roa-sbe@maastrichtuniversity.nl

www.roa.nl

Maastricht University

School of Business and Economics 